\title{
Long-Term Effects of Hard Coal Fly Ash on Selected Soil Properties
}

\author{
Zdzisław Ciećkoo ${ }^{1,2}$, Andrzej C. Żołnowski ${ }^{1 *}$, Monika Madej², \\ Grażyna Wasiak ${ }^{2}$, Janusz Lisowski ${ }^{3}$ \\ 'Department of Environmental Chemistry, University of Warmia and Mazury in Olsztyn, Poland \\ ${ }^{2}$ Faculty of Ecology, Higher School of Ecology and Management in Warsaw, Poland \\ ${ }^{3}$ Higher School of Agribusiness in Łomża, Poland \\ Received: November 20, 2014 \\ Accepted: January 11, 2015
}

\begin{abstract}
This research reports and analyzes results of a field experiment started in 1984, when hard coal fly ash

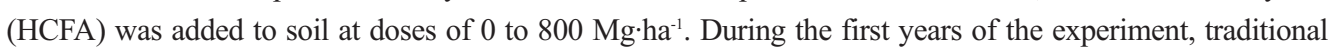
crops were grown in the plots, which in 1992 were converted into permanent grassland. Twenty-nine years after the application of fly ash, soil samples from the $0-20 \mathrm{~cm}$ soil layer were collected to determine chemical properties of soil. The results showed an elevated soil reaction, and high contents of available forms of $\mathrm{P}, \mathrm{K}$, and $\mathrm{Mg}$, plus mineral forms of nitrogen and high soil organic matter. Under increased ash doses, analysed soils increased the C:N ratio and shares of $\mathrm{N}-\mathrm{NO}_{3}$ and $\mathrm{N}-\mathrm{NH}_{4}$ in total nitrogen content. These results justify that fly ash from combustion of hard coal in a power plant can produce long-term impact on soil, contributing to a certain improvement of its chemical, physical, and biological properties, which stimulate the sequestration of carbon in soil.
\end{abstract}

Keywords: hard coal fly ash, $\mathrm{SOM}$, total $\mathrm{N}, \mathrm{N}-\mathrm{NO}_{3}, \mathrm{NH}_{4}$

\section{Introduction}

The legal regulations in Europe pertaining to the protection of air stipulate that the permissible levels of fly ash emissions from hard coal combustion in power plants generating $<500 \mathrm{MW}$ and $>500 \mathrm{MW}$ are 100 and $50 \mathrm{mg} \cdot \mathrm{m}^{-3}$, respectively [1-3]. Once implemented, these threshold limits have largely restrained dust emissions from the power generation sector and other industries. For example, ash emissions in Poland fell from about 115,000 tons in 2000 to 76,000 tons in 2011 (the data encompass power generating plants, heat generating plants, industrial power plants, and industrial technologies, but exclude local boilers, household furnaces, small workshops, agricultural facilities, etc.) [4]. Such a large reduction has been possible owing to high-

*e-mail: andrzej.zolnowski@uwm.edu.pl efficiency dust collectors, able to remove up to $98 \%$ of dust produced during the combustion of solid fuels, such as hard or brown coal. However, reduction in the dust emission increases the amounts of fly ash deposited on landfills near energy-generating plants. Covering more and more land, such dumping sites reduce the total surface of healthy and sustainable terrestrial habitats $[5,6]$. It is estimated that in 2011, about $99.7 \%$ of the dust mass generated all over Poland was captured and removed through dust collectors [7], indicating that more than 75,000 tons of this waste was deposited in landfills at power and heat generating plants. Hence, the proper management and utilization of fly ash, a by-product of electricity or heat generation, is important. While containing elements that can be useful to soil and plants, fly ash gathered in heaps on landfills acts as an aggressive and adverse factor toward ecosystems [8]. A large share of alkaline elements in the chemical compo- 
Table 1. Some physicochemical properties of soil used in the experiment.

\begin{tabular}{|c|c|c|c|c|c|c|}
\hline \multirow{2}{*}{$\begin{array}{c}\text { Soil/ } \\
\text { Properties }\end{array}$} & \multirow[t]{2}{*}{$\mathrm{pH}_{\mathrm{KCl}}$} & \multirow[t]{2}{*}{$\mathrm{pH}_{\mathrm{H}_{2} \mathrm{O}}$} & Hydrolytic acidity & $\begin{array}{c}\text { Bases Alkaline } \\
\text { Cations }\end{array}$ & $\begin{array}{l}\text { Cation Exchange } \\
\text { Capacity CEC }\end{array}$ & \multirow{2}{*}{$\begin{array}{c}\text { Total Base } \\
\text { Saturation }[\%]\end{array}$} \\
\hline & & & \multicolumn{3}{|c|}{$\left[\mathrm{cmol} \cdot \mathrm{kg}^{-1}\right]$} & \\
\hline \multirow{4}{*}{ Fluvisol } & 5.60 & 6.50 & 3.56 & 8.90 & 12.46 & 71.42 \\
\hline & \multicolumn{6}{|c|}{ Available forms of nutrients $\left[\mathrm{mg} \cdot \mathrm{kg}^{-1}\right]$} \\
\hline & $\mathrm{P}$ & $\mathrm{K}$ & $\mathrm{Mg}$ & $\mathrm{B}$ & & \\
\hline & 55 & 152 & 55 & 0.45 & & \\
\hline
\end{tabular}

Table 2. Some physicochemical properties of ash used in the experiment.

\begin{tabular}{|c|c|c|c|c|c|c|c|}
\hline \multirow{3}{*}{ Ash/properties } & \multirow{2}{*}{$\mathrm{pH}_{\mathrm{KCl}}$} & \multicolumn{6}{|c|}{ Total forms of macronutrients $\left[\mathrm{g} \cdot \mathrm{kg}^{-1}\right]$} \\
\cline { 2 - 8 } & & $\mathrm{SiO}_{2}$ & $\mathrm{P}$ & $\mathrm{K}$ & $\mathrm{Ca}$ & $\mathrm{Mg}$ & $\mathrm{Fe}$ \\
\cline { 2 - 8 } & 9.20 & 491 & 1.7 & 2.9 & 15.0 & 7.1 & 27.9 \\
\hline \multirow{3}{*}{$\mathrm{HCFA}$} & \multicolumn{7}{|c|}{ Total forms of micronutrients $\left[\mathrm{mg} \cdot \mathrm{kg}^{-1}\right]$} \\
\cline { 2 - 8 } & $\mathrm{Mn}$ & $\mathrm{Cu}$ & $\mathrm{Zn}$ & $\mathrm{Co}$ & \\
\cline { 2 - 8 } & 496 & 61 & 48 & 13 & & \\
\hline
\end{tabular}

sition of fly ash (6.0-23.4\% $\mathrm{CaO}$ and $0.9-2.0 \% \mathrm{MgO}$ [9]) suggests that this waste can be used to neutralize the reaction of acid soils [8, 10-19]. In some European countries, for example Germany, Denmark, France, and the UK (as well as in the USA), more than $70 \%$ of fly ash on average is used as raw material in the construction industry. In Asian countries, on the other hand, such usage is less common, e.g. just $38 \%$ of fly ash in India and $45 \%$ in China is recycled by the building industry $[20,21]$. The question of using fly ash by agriculture is highly controversial. One reason is the potential risk of polluting the natural environment with heavy metals like $\mathrm{Cu}, \mathrm{Sr}, \mathrm{Ni}, \mathrm{Cr}, \mathrm{Zn}, \mathrm{Cd}, \mathrm{Mo}, \mathrm{Se}, \mathrm{Pb}$, As, V, Hg, Ba, Th, and B [8, 11, 21-23]. The direct effect of fly ash from hard coal on soil properties has been investigated rather thoroughly [11, 16, 24]. In contrast, reports on the lasting effects of fly ash on the chemical properties of soils are scarce.

Our objective has been to determine whether fly ash obtained by burning hard coal in power generating plants produces a long-term effect on the soil reaction and its content of macronutrients and humus. This thesis has been verified against the background of a null hypothesis stating that no difference between the analyzed objects would occur 29 years after the application of fly ash.

\section{Materials and Methods}

\section{Experimental Design}

In 1984 a field experiment was established in the village of Łęg Starościński in the province of Mazowsze $\left(53^{\circ} 11^{\prime} 30.81^{\prime \prime N}\right.$; 21 $\left.1^{\circ} 57^{\prime} 20.20^{\prime \prime} \mathrm{E}\right)$. The soil was fluvisol
(FL) with the textural composition of sandy loam (SL) (63\% sand, 30\% silt, and 7\% clay) according to World Reference Base [25]. Physicochemical properties of soil at the beginning of the experiment are shown in Table 1 .

The experiment was designed in line with the random block method including four replications. The first experimental factor consisted of increasing doses $(0,100,200$, 400,600 , and $800 \mathrm{Mg} \cdot \mathrm{ha}^{-1}$ ) of hard coal fly ash (HCFA) from electrofilters working at the Ostrołęa Power Plants. The total content of elements per $1 \mathrm{~kg}$ of dry matter of HCFA are shown in Table 2.

The second experimental factor included organic soil amendments: farmyard manure, straw and tree bark applied to soil together with fly ash, in the amount of $10 \mathrm{t}$ dry matter per ha. The analyses performed in 2003 did not reveal any significant differences between the experimental series in which different organic substances had been used, which is why since then the experiment has been treated as a single factor one, in which the only factor considered was the difference in the doses of fly ash, and the treatments in the individual series were perceived as four replications. The plots (each $54 \mathrm{~m}^{2}$ in area) which composed a single block were separated from one another with $1 \mathrm{~m}$ wide belts, while the blocks were divided by $3 \mathrm{~m}$ wide belts. Hard coal fly ash was applied in autumn 1984 under winter ploughing, by mixing with the arable layer of soil. In the consecutive six years, the plots were cropped with typical agricultural plants: potatoes (1985), oat for green mass+lupine for green mass (1986), rye for green mass + a mix of legumes and grasses for green mass (1987), and a legume-grass mix for green mass in 1988-91. Since 1992, the whole field has been maintained as permanent grassland and not fertilized with mineral fertilizers. 


\section{Soil Sampling}

In 2013, that is 29 years after the application of fly ash, soil samples were taken from all treatments at a depth of $0-20 \mathrm{~cm}$. The sampling was done with an Egner's core sampler. Samples were collected from four sites on each plot and then averaged into an aggregated sample. Consequently, four separate replications were obtained for each treatment. Soil samples collected for analyses were placed on trays and air dried, after which they were passed through a sieve with a $1.0 \mathrm{~mm}$ diameter. Samples thus prepared for analyses were kept in airtight plastic containers.

\section{Soil Analyses}

The soil reaction was determined by potentiometry in $1 \mathrm{M} \mathrm{KCl}$ and $\mathrm{H}_{2} \mathrm{O}$ in a 1:2.5 soil-to-solution ratio [26]. The determinations were done potentiometrically after 24 hours, with an HI 221 potentiometer (Hanna Instruments).

The contents of available $\mathrm{P}$ and $\mathrm{K}$ were determined after the extraction of soil with calcium lactate solution [27]. Having been transformed into phosphorus molybdenum blue, phosphorus in the soil extract was determined by the colorimetric method, in a reaction with ammonium molybdate and Photorex and with stannous chloride $\mathrm{SnCl}_{2}$ on a Merck SQ118spectrocolorimeter (Merck KGaA, Germany). Potassium was determined by atomic emission spectroscopy (FAES) on Flapho 4, (Carl Zeiss Jena, Germany), after calcium had been precipitated and the sample had been passed through a filter.

The content of available $\mathrm{Mg}$ was determined after soil extraction with a solution of $0.0125 \mathrm{M} \mathrm{CaCl}_{2}$, at a soil-tosolution m:v ratio of 1:10 [28]. Magnesium was determined using flame atomic absorption spectroscopy (FAAS) on an AAS 1 apparatus (Carl Zeiss Jena, Germany).

The content of total nitrogen (ToN) was determined with a modified Kjeldahl's method [29], having mineralized the soil samples in infrared in Turbotherm TT 125 Rapid Digestion Systems (Gerhardt Fabrik und Lager Chemischer Apparate $\mathrm{GmbH} \&$ Co. KG Germany). Samples were mineralized in concentrated sulphuric acid, using selenium mixture in the form of tablets (3.5 g $\left.\mathrm{K}_{2} \mathrm{SO}_{4}+0.0035 \mathrm{~g} \mathrm{Se}\right)$ as a catalyst. A Büchi B-324 (BÜCHILabortechnik AG, Switzerland) distillation unit was employed for the distillation of nitrogen. Samples were titrated with $0.1 \mathrm{MNaOH}$ solution titrated against the Tashiro reagent (POCh Gliwice, Poland) as an indicator. The reaction was carried out on a Schott TITRONIC universal apparatus (SCHOTT-GERÄTE GmbH, Germany).

$\mathrm{N}-\mathrm{NO}_{3}^{-}$and $\mathrm{N}-\mathrm{NH}_{4}^{+}$in soil samples were determined after soil extraction with $1 \% \mathrm{~K}_{2} \mathrm{SO}_{4}$ solution, using the continuous flow analysis (CFA) technique with spectrometric detection on a Skalar ${ }^{++}$apparatus and a chemical section SA 3000/5000 (Skalar Analytical B.V., the Netherlands) according to Skalar methods [30, 31].

The content of organic carbon (OC) in soil was determined with a modified Tiurin's method on a Spectronic GENESYS 6 spectrocolorimeter (Thermo Electron
Scientific Instruments LLC, Madison, WI, USA) [32]. The content of soil organic matter (SOM) was derived from the content of OC using Van Bemmelen's index $=1.724$, whose value had been calculated from the assumption that SOM contained $58 \%$ of OC [33].

\section{Statistical Analysis}

The results underwent statistical processing according to the one-way analysis of variance at the level of significance $\mathrm{P}=0.05$, using the statistical calculation module of Statistica v. 10.0 [34]. The limit ranges (LSD) were determined with the one-dimensional Duncan's test, while the homogenous groups were distinguished with the NewmanKeulus's test. The standard error $( \pm \mathrm{SE})$ and power of the correlation between a dose of fly ash and soil chemical properties, expressed by Pearson's simple correlation coefficient was calculated with the aid of MS Excel 2010 [35]. The statistical significance of correlation coefficients at n-2 degrees of freedom was assessed according to tables of critical values [36] at the levels of significance $\alpha=0.05(*)$ and $\alpha=0.01(* *)$, at which point the correlation was significant or highly significant, respectively. Frequency of the pairs of observations (n) of the above determinations is explained in the description underneath the tables and figures.

\section{Results and Discussion}

\section{Soil Reaction and Available Phosphorus, Potassium, and Magnesium}

The influence of HCFA on soil 29 years after its application of chemical properties is shown in Table 3 . In response to HCFA introduced to soil in doses over 100 $\mathrm{Mg} \cdot \mathrm{ha}^{-1}$, a significant increase was noticed in the soil $\mathrm{pH}$, measured in both $\mathrm{H}_{2} \mathrm{O}$ and $1 \mathrm{M} \mathrm{KCl}$. This de-acidifying effect on the soil reaction determined in water was noticed up to the dose of $600 \mathrm{Mg} \mathrm{HCFA} \cdot \mathrm{ha}^{-1}$. As regards $\mathrm{pH}$ in $1 \mathrm{M}$ $\mathrm{KCl}$, the effect continued up to the dose of $800 \mathrm{Mg}$ HCFA $\cdot \mathrm{ha}^{-1}$. The lasting de-acidifying influence of HCFA was further confirmed by highly significant coefficients of the correlation ( $\mathrm{r}$ ) between a dose of fly ash and reaction of soil samples (Table 3). Ainsworth and Rai [37] claim that that the de-acidifying power of fly ash depends, among others, on the type and origin of coal from which the ash was obtained, on its chemical composition, including $\mathrm{Si}, \mathrm{Al}$, and $\mathrm{Fe}$, as well as alkaline cations such as $\mathrm{Ca}, \mathrm{K}, \mathrm{Na}$, and $\mathrm{Ti}$. The reaction of raw ash can range from 4.5 to 12.0 (in our study, the $\mathrm{pH}$ in $1 \mathrm{M} \mathrm{KCl}$ was 9.2). The $\mathrm{pH}$ of fly ash is mostly dependent on the content of sulphur and its ratio to calcium [37]. In the vast majority of cases, combustion of hard coal generates alkaline ash, and the calcium it contains can enter in lasting interactions with the soil components that are acidic, e.g. sulphur, boron, or molybdenum. According to Bielińska et al. [8], ash can be an alternative substance to classical liming materials, at no detriment to important metabolic processes that shape the quality of soil, as demonstrated by the present study, where permanent and 
Table 3. Effects of HCFA on soil $\mathrm{pH}$ and available forms of macronutrient content in surface soil layer after 29 years of ash application.

\begin{tabular}{|c|c|c|c|c|c|}
\hline \multirow{2}{*}{$\begin{array}{c}\text { HCFA dose } \\
{\left[\mathrm{Mg} \cdot \mathrm{ha}^{-1}\right]}\end{array}$} & \multicolumn{2}{|c|}{$\mathrm{pH}$} & \multicolumn{3}{c|}{ Available forms $\left[\mathrm{mg}^{-k^{-1}}\right]$} \\
\cline { 2 - 6 } & $\mathrm{H}_{2} \mathrm{O}$ & $1 \mathrm{M} \mathrm{KCl}$ & $\mathrm{P}$ & $\mathrm{K}$ & $\mathrm{Mg}$ \\
\hline 0 & $5.88^{\mathrm{a}} \pm 0.03$ & $5.01^{\mathrm{a}} \pm 0.05$ & $56.35^{\mathrm{a}} \pm 4.83$ & $61.45^{\mathrm{a}} \pm 15.26$ & $63.50^{\mathrm{a}} \pm 4.50$ \\
\hline 100 & $5.88^{\mathrm{a}} \pm 0.03$ & $4.98^{\mathrm{a}} \pm 0.04$ & $70.02^{\mathrm{b}} \pm 5.36$ & $94.14^{\mathrm{b}} \pm 11.63$ & $64.25^{\mathrm{a}} \pm 4.44$ \\
\hline 200 & $6.15^{\mathrm{b}} \pm 0.12$ & $5.54^{\mathrm{b}} \pm 0.15$ & $72.43^{\mathrm{b}} \pm 10.87$ & $94.60^{\mathrm{b}} \pm 3.73$ & $93.25^{\mathrm{b}} \pm 5.36$ \\
\hline 400 & $6.43^{\mathrm{c}} \pm 0.10$ & $6.10^{\mathrm{c}} \pm 0.05$ & $83.43^{\mathrm{c}} \pm 5.13$ & $95.48^{\mathrm{b}} \pm 3.85$ & $115.75^{\mathrm{c}} \pm 9.65$ \\
\hline 600 & $6.70^{\mathrm{d}} \pm 0.02$ & $6.28^{\mathrm{d}} \pm 0.14$ & $87.28^{\mathrm{c}} \pm 2.90$ & $96.74^{\mathrm{b}} \pm 4.43$ & $130.00^{\mathrm{d}} \pm 5.00$ \\
\hline 800 & $6.72^{\mathrm{d}} \pm 0.06$ & $6.48^{\mathrm{c}} \pm 0.10$ & $94.10^{\mathrm{c}} \pm 2.51$ & $98.03^{\mathrm{b}} \pm 13.82$ & $121.75^{\mathrm{cd}} \pm 6.94$ \\
\hline Average & $6.29 \pm 0.36$ & $5.73 \pm 0.60$ & $77.27 \pm 13.82$ & $90.07 \pm 16.33$ & $98.08 \pm 27.36$ \\
\hline LSD $_{(0.05)}$ & 0.12 & 0.17 & 10.19 & 17.27 & 10.74 \\
\hline$r$ & $0.90^{* *}$ & $0.89^{* *}$ & $0.87^{* *}$ & $0.50^{*}$ & $0.88^{* *}$ \\
\hline
\end{tabular}

Values given are means of four replicates \pm standard errors, different letters near value indicate significant differences between the treatments at $\mathrm{P}=0.05$. Simple Pearson's correlation coefficient $(r)$ between HFCA dose and investigated parameters: $* r-$ significant for $\alpha=0.05, * * r$ significant for $\alpha=0.01, \mathrm{~ns}-$ not significant; $\mathrm{n}=24$

beneficial changes in the soil reaction were proven. The positive effect of fly ash on soil comprises other physical characteristics and the content of nutrients in soil [38]. The HCFA applied 29 years before continued to affect the content of available forms of phosphorus, potassium, and magnesium in soil. It has been demonstrated that doses of 100 and $400 \mathrm{Mg} \mathrm{HCFA} \cdot$ ha $^{-1}$ acted beneficially on the content of phosphorus, raising the level of available $P$ forms by 13.67 and $27.05 \mathrm{mg} \cdot \mathrm{kg}^{-1}$ of soil, respectively, compared to the control soil. Panthan et al. [39] also showed a 2.5- to 4.5-fold increase in the content of extractable phosphorus in response to the application of HCFA compared to the control (not treated with fly ash). In our investigations, the content of available potassium increased under the influence of HCFA, but only when $100 \mathrm{Mg} \mathrm{HCFA} \cdot \mathrm{ha}^{-1}$ had been applied.

Although higher doses of fly ash did not change the soil content of available potassium significantly, they did alter the soil content of extractable magnesium. For example an application of $200 \mathrm{MgHCFA} \cdot \mathrm{ha}^{-1}$ as well as 400 and 600 $\mathrm{Mg} \mathrm{HCFA} \cdot \mathrm{ha}^{-1}$ resulted in a significant rise in the content of $\mathrm{Mg}$ versus the control soil. Despite the 29-year lapse of time since the application of fly ash, high coefficients of the correlation between HCFA dose and content of available $\mathrm{P}$ and $\mathrm{Mg}\left(\mathrm{r}=0.87^{* *}, \mathrm{r}=0.88^{*}\right)$ as well as $\mathrm{K}\left(\mathrm{r}=0.50^{*}\right)$ prove that HCFA maintained a strong residual effect on the above nutrients. The observed positive influence of fly ash on the elevated concentrations of macroelements in soil is verified by literature [10, 23, 40], and this finding gains importance in the context of possible utilization of ash from biomass combustion [17, 41].

\section{Content of Total Nitrogen and Mineral Nitrogen Forms}

The total nitrogen content (ToN) and mineral nitrogen forms in soil from the analyzed plots varied. Despite being unable to demonstrate significant differences between the plots in terms of ToN, we can point to a highly significant correlation coefficient $(\mathrm{r}=0.59 * *)$ implicating a strong and previously verified [13] relationship between the ToN content and a dose of HCFA (Fig. 1). The content of nitrate nitrogen $\left(\mathrm{N}_{-} \mathrm{NO}_{3}\right)$ in the analyzed soil samples was significantly elevated, on average by $20.3,25.9$, and $31.9 \%$ versus the CS, following the application of 400,600 , and 800 $\mathrm{Mg}$ HCFA $\cdot \mathrm{ha}^{-1}$, respectively. The stimulating effect of HCFA was even stronger in the case of ammonia nitrogen. The content of $\mathrm{N}^{-\mathrm{NH}_{4}^{+}}$relative to the CS was 24.6 and $39.4 \%$ higher after the application of 400 and $800 \mathrm{Mg}$ HCFA $\cdot \mathrm{ha}^{-1}$, respectively. The strong relationship between the dose of HCFA and the content of mineral forms of nitrogen is confirmed by highly significant correlation coefficients $\left(\mathrm{r}=0.96^{* *}\right.$ and $\mathrm{r}=0.97^{* *}$ for the sum of $\mathrm{N}^{*} \mathrm{NO}_{3}+$ $\mathrm{N}-\mathrm{NH}_{4}^{+}$). The higher abundance of $\mathrm{N}-\mathrm{NO}_{3}$ and $\mathrm{N}-\mathrm{NH}_{4}^{+}$may be a consequence of the limited leaching of mineral nitrogen forms from soils treated with HCFA. This thesis is supported by the lysimetric experiments conducted by Pathan et al. [39], where the accumulated leaching of $\mathrm{N}-\mathrm{NO}_{3}$ and $\mathrm{N}-\mathrm{NH}_{4}$ from plots with a $20 \%$ contribution of fly ash into the surface layer of soil was approximately $2.0\left(\mathrm{~N}^{-N_{3}}\right)$ and $0.2 \mathrm{mg} \cdot \mathrm{m}^{-2}\left(\mathrm{~N}_{-} \mathrm{NH}_{4}\right)$ lower than from the control object, without fly ash. Although the above authors did not show a significant effect of fly ash application on the content of extractable forms of $\mathrm{N}-\mathrm{NO}_{3}$ and $\mathrm{N}-\mathrm{NH}_{4}$, a clear tendency appeared for a higher soil content of these forms of nitrogen in response to the amelioration of soil with HCFA. In the present study, the ameliorating doses of fly ash applied 29 years earlier also elevated the share of the mineral nitrogen forms in ToN. It was shown that the dose significantly raising this share was the amount of $400 \mathrm{Mg} \mathrm{HCFA} \cdot$ ha $^{-1}$ (Fig. 2).

Hard coal fly ash as waste produced by heat and power generating plants contains minute quantities of nitrogen. During the combustion process, nitrogen is mostly emitted to the atmosphere in the form of oxides, and the N-total amount in fly ash is no more than a few tenths of a percent 
ToN $\left[\mathrm{g} \cdot \mathrm{kg}^{-1}\right]$

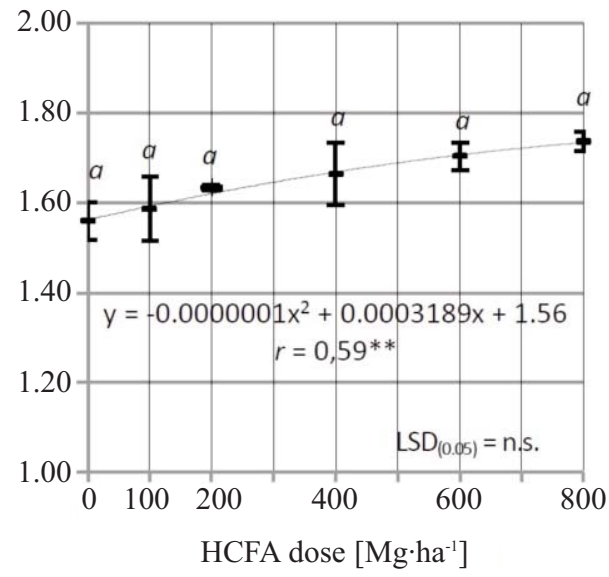

$\mathrm{N}-\mathrm{NH}_{4}\left[\mathrm{mg} \cdot \mathrm{kg}^{-1}\right]$

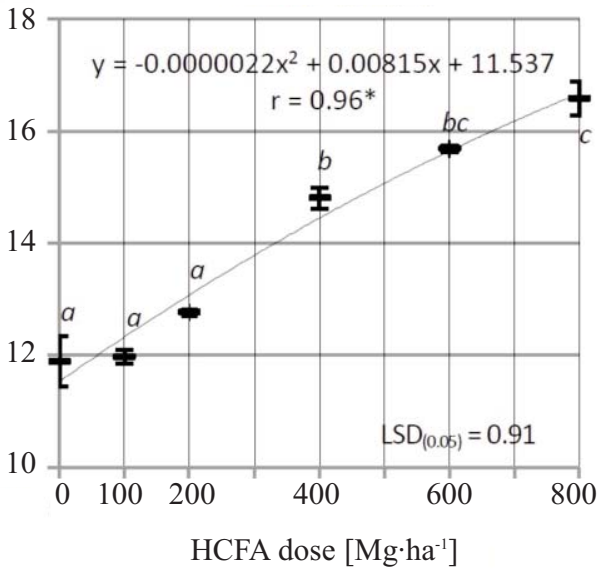

$\mathrm{N}-\mathrm{NO}_{3}\left[\mathrm{mg} \cdot \mathrm{kg}^{-1}\right]$

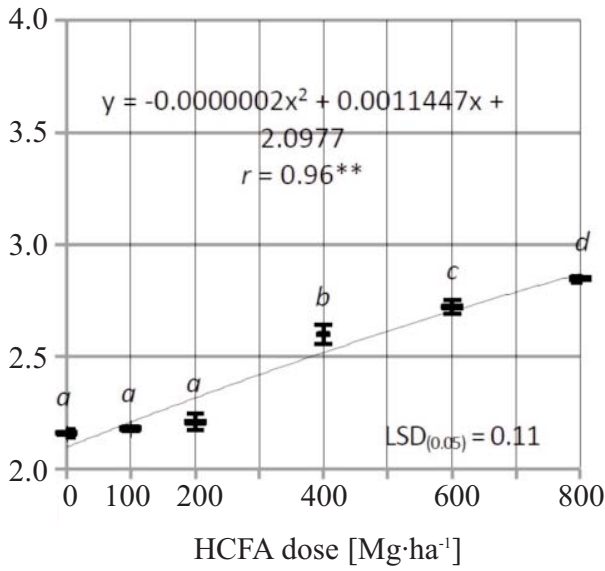

$\mathrm{N}-\mathrm{NH}_{4}+\mathrm{N}-\mathrm{NO}_{3}\left[\mathrm{mg} \cdot \mathrm{kg}^{-1}\right]$

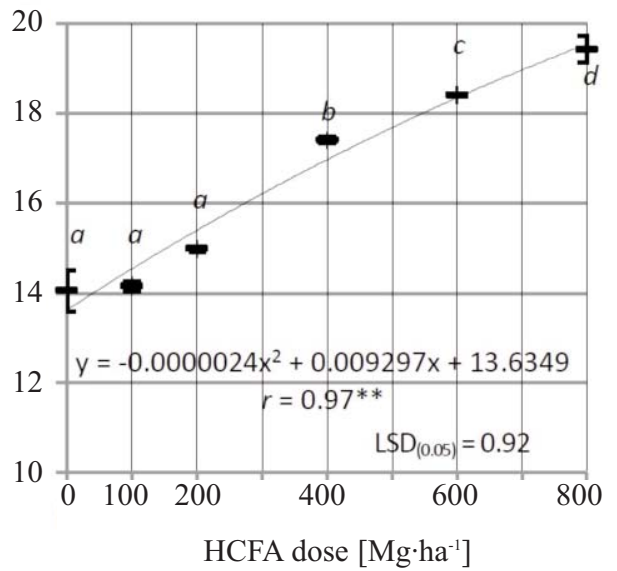

Fig. 1. Effect of HFCA on ToN, ${\mathrm{N}-\mathrm{NO}_{3}}_{3}$, and $\mathrm{N}-\mathrm{NH}_{4}$ content in surface soil layer 29 years after ash application.

Different letters on the marks indicate significant differences between the treatments. Pearson's simple correlation coefficient $(r)$ between HFCA dose and nitrogen forms content: ${ }^{*} r$ - significant for $\alpha=0.05, *^{*} r-$ significant for $\alpha=0.01$, ns - not significant; $\mathrm{n}=24$.

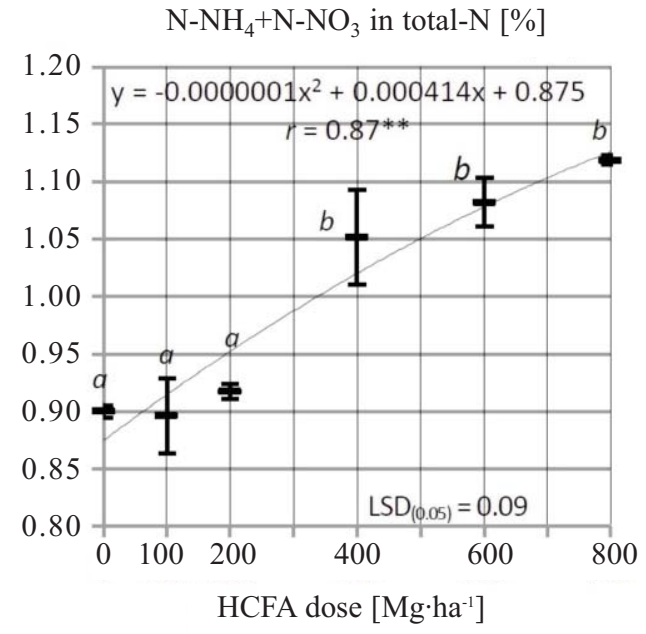

Fig. 2. Effect of HFCA on the share of $\mathrm{N}-\mathrm{NH}_{4}+\mathrm{N}-\mathrm{NO}_{3}$ in $\mathrm{ToN}$ in the surface soil layer 29 years after ash application. Different letters on the marks indicate significant differences between the treatments. Simple Pearson's correlation coefficient $(r)$ between HFCA dose and nitrogen forms content: $* r-$ significant for $\alpha=0.05, * * r$ - significant for $\alpha=0.01$, ns not significant; $\mathrm{n}=24$
(ToN 0.2\%) [42]. In this context, HCFA cannot be perceived as a source of nitrogen for plants. Notwithstanding this, our study has shown that incremental HCFA doses applied in the distant past significantly differentiate the content of ToN, $\mathrm{N}-\mathrm{NO}_{3}$, and N-NH $\mathrm{N}_{4}^{+}$in soil. Adriano and Weber [43] claim that the betterment of conditions for the growth and development of plants induced by HCFA fertilization is caused by a change in the physical properties of soil. The cited researchers used fly ash in doses between 280 and $1120 \mathrm{Mg} \cdot \mathrm{ha}^{-1}$, and reported a significant increase in the water-holding capacity (WCH) as well as the content of water available to plants. Besides the higher WHC of soil in response to fly ash, Yeledhalli et al. [44] demonstrated that HCFA in soil improved soil porosity. Such changes result in improved air and water conditions in soil, which in our research, for example, led to the formation of deeper and more abundant root systems by all the cultivated plant species. Some earlier studies by Ciećko et al. [45] proved a positive effect of HCFA applied in doses of $200 \mathrm{t}^{-h \mathrm{a}^{-1}}$ on meadow sward, which produced higher yields. This observation has been verified by several other studies on the agricultural utilization of ash from power 
generating plants. As reported by Jala and Goyal [16], higher yields owing to fly ash fertilization have been achieved by such plants as alfalfa (Medicago sativa), barley (Hordeumvulgare), Bermuda grass (Cynodondactylon), and white clover (Trifoliumrepens). Grewal et al. [46] showed that a $5-20 \%$ addition of fly ashes to the topsoil layer $(0-15 \mathrm{~cm})$ resulted in higher yields of grain and straw from pearlmillet (Pennisetum sp.) grown after wheat. Positive results were also obtained while growing teak trees (Tectonagrandis) and leucaena (Leucaenaleucocephala) [47]. In our experiment, higher plant yields have led to higher accumulation of plant residue in soil, which is a valuable source of available nitrogen for subsequent plants. Owing to the increased soil porosity and water holding capacity, the leaching of mineral $\mathrm{N}$ forms is limited, as reported by Pathan et al. [39].

\section{Soil Organic Matter and C:N Ratio}

The fly ash originating from a power plant and added to soil 29 years prior to our analyses affected the content of SOM. It has been demonstrated that the plots amended with $200 \mathrm{Mg} \mathrm{HCFA} \cdot \mathrm{ha}^{-1}$ had a higher content of humus compared to the CS. The increase reached $3.54 \mathrm{~g} \mathrm{SOM} \cdot \mathrm{kg}^{-1}$, which corresponds to $10.7 \%$. The plots amended with higher doses of HCFA, i.e. 400 and $600 \mathrm{Mg} \mathrm{HCFA} \cdot \mathrm{ha}^{-1}$, composed a statistically homogenous group and were characterized by an average $27.0 \%$ increase in the humus content versus the CS. Another significant rise in the SOM content was achieved on the plot fertilized with $800 \mathrm{Mg} \mathrm{HCFA} \cdot \mathrm{ha}^{-1}$. There, the SOM content was $16.77 \mathrm{~g} \cdot \mathrm{kg}^{-1}$ of soil, which was $50.5 \%$ higher than in the soil not treated with HCFA. The SOM content was significantly positively correlated with all the analyzed parameters except potassium content (Fig. 3).

The soil samples were also compared with respect to the $\mathrm{C}: \mathrm{N}$ ratio. In Polish soils, typical values of this parameter are from 7.4 to17.4, and the average value is 10.4 [48].
In our investigations, the $\mathrm{C}: \mathrm{N}$ ratio in the soil samples was within 12.4-16.6. The applied ash significantly widened this ratio, which was demonstrated in the soils fertilized with 200, 400, and $800 \mathrm{Mg} \mathrm{HCFA} \cdot \mathrm{ha}^{-1}$. The $\mathrm{C}: \mathrm{N}$ ratio was significantly positively correlated with almost all the analyzed parameters except the content of potassium and nitrogen (Table 4). The widening of the $\mathrm{C}: \mathrm{N}$ ratio in plots amended with HCFA points to processes is associated with a more intensive carbon sequestration, stimulated by the aforementioned higher accumulation of plant residue and roots in soil. A number of studies on HCFA carried out worldwide imply the significant influence of this waste material on the accumulation of organic and inorganic carbon in soil, which may follow a different course and occur with a different degree of intensity [49]. Such changes depend on the chemical and physical characteristics of both fly ash and soil. More intensive sequestration of $\mathrm{OC}$ in HCFA-treated soils is mostly a result of the microbiological decomposition of plant and animal waste to simple sugars, amino acids, and cellulose. At subsequent stages, however, these substances are decomposed by soil-borne microorganisms to simple compounds, including $\mathrm{CO}_{2}$ released to the atmosphere. When viewing the above transformations in the long run, it can be concluded that parallel processes of synthesis connected with the humification of organic matter in HCFA-treated objects leads to the formation of soil organic matter that is more resistant to decomposition by microorganisms, which is explained by specific interactions with the soil's mineral phase and its structure [11, 50].

\section{Conclusions}

1. Fly ash originating from combustion of hard coal and applied in the form of ameliorating doses between 200$800 \mathrm{Mg}$ HCFA $\cdot \mathrm{ha}^{-1}$ permanently raised the soil $\mathrm{pH}$ and content of available forms of phosphorus, potassium, and magnesium in soil.
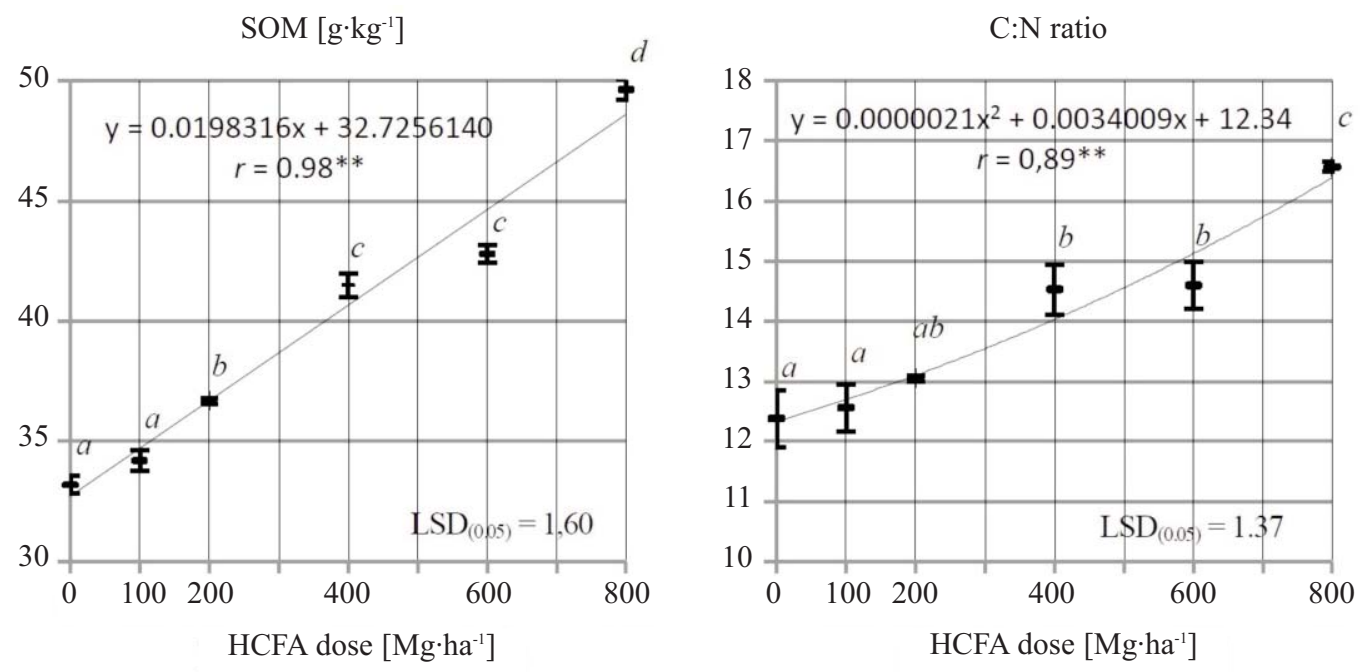

Fig. 3. Effect of HFCA on SOM content and C:N ratio in surface soil layer 29 years after ash application.

Different letters on the marks indicate significant differences between the treatments. Simple Pearson's correlation coefficient $(r)$ between HFCA dose and nitrogen forms content: ${ }^{*} r$ - significant for $\alpha=0.05,{ }^{*} r-$ significant for $\alpha=0.01$, ns - not significant; $\mathrm{n}=24$. 
Table 4. Pearson's simple correlation coefficients between soil chemical properties 29 years after HCFA application.

\begin{tabular}{|c|c|c|c|c|c|c|c|c|c|c|c|}
\hline Variable & 1 & 2 & 3 & 4 & 5 & 6 & 7 & 8 & 9 & 10 & 11 \\
\hline \multicolumn{12}{|l|}{ 1. $\mathrm{pH}_{\mathrm{H}_{2} \mathrm{O}}$} \\
\hline 2. $\mathrm{pH}_{\mathrm{KCl}}$ & $0.96^{* *}$ & & & & & & & & & & \\
\hline 3. $\mathrm{P}$ & $0.87 * *$ & $0.89 * *$ & & & & & & & & & \\
\hline 4. $\mathrm{K}$ & 0.37 & 0.38 & $0.55 * *$ & & & & & & & & \\
\hline 5. $\mathrm{Mg}$ & $0.94 * *$ & $0.97 * *$ & $0.82 * *$ & 0.38 & & & & & & & \\
\hline 6. Total N & $0.61 * *$ & $0.61 * *$ & $0.53 * *$ & 0.18 & $0.61 * *$ & & & & & & \\
\hline 7. $\mathrm{NH}_{4}$ & $0.94 * *$ & $0.95^{* *}$ & $0.84 * *$ & 0.32 & $0.91 * *$ & $0.65^{* *}$ & & & & & \\
\hline 8. $\mathrm{N}-\mathrm{NO}_{3}$ & $0.94 * *$ & $0.93 * *$ & $0.81 * *$ & 0.33 & $0.90 * *$ & $0.61 * *$ & $0.96^{* *}$ & & & & \\
\hline 9. $\mathrm{NH}_{4}+\mathrm{N}-\mathrm{NO}_{3}$ & $0.94 * *$ & $0.95 * *$ & $0.84 * *$ & 0.33 & $0.91 * *$ & $0.65^{* *}$ & $1.00^{* *}$ & $0.97 * *$ & & & \\
\hline 10. $\mathrm{N}-\mathrm{NH}_{4}+\mathrm{N}-\mathrm{NO}_{3}$ in $3 \mathrm{ToN}$ & $0.83 * *$ & $0.85^{* *}$ & $0.75 * *$ & 0.33 & $0.80 * *$ & 0.23 & $0.88 * *$ & $0.87 * *$ & $0.89 * *$ & & \\
\hline 11. SOM & $0.92 * *$ & $0.93 * *$ & $0.86^{* *}$ & 0.36 & $0.85^{* *}$ & $0.61 * *$ & $0.94 * *$ & $0.94 * *$ & $0.95 * *$ & $0.84 * *$ & \\
\hline 12. C:N & $0.81 * *$ & $0.83^{* *}$ & $0.78 * *$ & 0.36 & $0.74 * *$ & 0.22 & $0.82 * *$ & $0.83^{* *}$ & $0.82 * *$ & $0.91 * *$ & $0.91 * *$ \\
\hline
\end{tabular}

* - correlation coefficient $r$ significant for $\alpha=0.05 ; * *$ correlation coefficient $r$ significant for $\alpha=0.01 ; n=24$

2. The HCFA incorporated into soil 29 years before were not found to have affected significantly the content of $\mathrm{ToN}$ in soil, although concentrations of $\mathrm{N}-\mathrm{NO}_{3}$ and $\mathrm{N}-\mathrm{NH}_{4}$ were shown to have been significantly increased, and the share of mineral $\mathrm{N}$ forms in the pool of ToN was higher as well.

3. Fly ash introduced to soil in doses above $200 \mathrm{Mg}$ HCFA $\cdot$ ha $^{-1}$ significantly increased the SOM content of soil while contributing to a significant widening of the $\mathrm{C}: \mathrm{N}$ ratio, which may implicate a significant, residual, and stimulating effect of HCFA on sequestration of carbon in soil.

4. The lasting changes in the chemical composition of the analyzed soils, found 29 years after the application of fly ash, cannot be attributed to any direct impact of HCFA but result from indirect effects such as improved physicochemical properties of soil, which created more suitable conditions for accumulation of available elements, mineral nitrogen forms, and organic carbon in soil.

\section{Abbreviations}

HCFA - hard coal fly ash,

ToN - total nitrogen,

OC - organic carbon,

SOM - soil organic matter,

$\mathrm{CS}$ - the control soil without addition of HCFA

\section{References}

1. DIRECTIVE 2001/80/EC OF THE EUROPEAN PARLIAMENT AND OF THE COUNCIL of 23 October 2001 on the limitation of emissions of certain pollutants into the air from large combustion plants. 27.11.2001 EN Official Journal of the European Communities L 309/1, 2001.

2. DIRECTIVE 2010/75/EU OF THE EUROPEAN PARLIAMENT AND OF THE COUNCIL of 24 November 2010 on industrial emissions (integrated pollution prevention and control) (Recast) (Text with EEA relevance). 17.12.2010 EN Official Journal of the European Union L 334/17, 2010.

3. DZ.U. 2011. REGULATION OF THE MINISTER OF THE ENVIRONMENT of 22 April $2011 \mathrm{r}$. on emission standards from facilities. Journal of Law 95, 558, 2011 [In Polish].

4. GUS Environment - Statistical Information and Elaborations. Central Statistical Office. 217, 2013 [In Polish].

5. SHAHEENS M., HOODA P.S., TSADILAS C.D. Opportunities and challenges in the use of coal fly ash for soil improvements - A review. J. Environ. Manage. 145, 249, 2014.

6. CIEĆKO Z., ŻOŁNOWSKI A.C., CHEŁSTOWSKI A. Long-term effect of coal fly ash application on soil total nitrogen and organic carbon concentrations. In: Application of Phytotechnologies for Cleanup of Industrial, Agricultural, and Wastewater Contamination. Ed. Kulakow P.A., Pidlisnyuk V.V. Series C: Environmental Scurity. Springer in cooperation with NATO Public Diplomacy Division. NATO Science for Peace and Security Series. 147, 2009.

7. GUS Environment - Statistical Information and Elaborations. Central Statistical Office. 211, 2012 [In Polish].

8. BIELIŃSKA E. J., BARAN S., STANKOWSKI S. Assessment of the suitability of hard coal fly ash for agricultural purposes. Inż. Rol. 6, (115), 7, 2009 [In Polish].

9. GONET A., STRYCZEK S., WOJCIECHOWSKI R. Compressive strength of cement and clay mortar with addition of the Żerań Heat and Power Plant fly ash. Wiertnictwo, Nafta, Gaz, 22, (2), 551, 2005 [In Polish].

10. WYSZKOWSKI M., CHEŁSTOWSKI A., CIEĆKO Z., SZOSTEK R. Long-time effect of hard coal ash on the content of some elements in soil. J. Ecol. Eng. 15, (1), 55, 2014. 
11. UKWATTAGEN L., RANJTTHP G., BOUAZZA M. The use of coal combustion fly ash as a soil amendment in agricultural lands (with comments on its potential to improve food security and sequester carbon). Fuel, 109, 400, 2013.

12. CIEĆKO Z., ŻOŁNOWSKI A. C., KULMACZEWSKA J., CHEŁSTOWSKI A. Residual effect of ameliorating doses of hard coal fly ash on soil acidity. Zesz. Probl. Post. Nauk Rol. 535, 73, 2009 [In Polish].

13. CIEĆKO Z., ŻOŁNOWSKI A.C., OSTROWSKA E., CHELSTOWSKI A. Long-time effect of hard coal fly ash application on the nitrogen content in soil. Ecol. Chem. Eng. 17, (6), 748, 2010.

14. VEERESH H., TRIPATHY S., CHAUDHURI D., GHOSH B.C., HART B.R., POWELL M.A. Changes in physical and chemical properties of three soil types in India as a result of amendment with fly ash and sewage sludge. Environ. Geol., 43, 513, 2003

15. MURKOWSKI A., STANKOWSKI S. Use of hard coal fly ash components in fertilization of triticale. Proceedings of IV Science Symposium 'Breeding, Cultivation and Use of Triticale'. 1-4. 09. 2002 Kołobrzeg, 29-31, 2002 [In Polish].

16. JALA S., GOYAL D. Fly ash as a soil ameliorant for improving crop production. A review. Bioresource Technol. 97, 1136, 2006.

17. MELLER E., BILENDA E. Effect of fly ash from biomass combustion on physicochemical properties of light soils. Polit. Energ. 15, (3), 287, 2012 [In Polish]

18. MELLER E. Influence of various doses of fly ash from combustion of hard coal at the Dolna Odra Power Plant on yield and chemical composition of crops. Fol. Univ. Agric. Stetin., Ser. Agricultura 201, (78), 203, 1999 [In Polish].

19. BOGACZ A., CHODAK T., SZERSZEŃ L. Studies on the use of fly ash from the power plant in Opole in agriculture. Zesz. Probl. Post. Nauk Rol. 418, 671, 1995 [In Polish].

20. PANDEY V.C. SINGH N. Impact of fly ash incorporation in soil systems. Agr. Ecosyst. Environ. 136, 16, 2010.

21. SHARMA S.K., KALRA N. Effect of flyash incorporation on soil properties and productivity of crops: A review. J. Sci. Ind. Res. 65, 383, 2006.

22. MAHALEN K., PATIL A.D., SARODED B., ATTARDE A.B. Effect of Fly Ash as an Admixture in Agriculture and Study of heavy metal accumulation in wheat (Trtiticumaestivum), mung bean (Vignaradiata), and urad beans (Vignamungo). Pol. J. Environ. Stud. 21, 1713, 2012.

23. LEE H., HA H.S. LEE C.H. LEE Y.B., KIM P.J. Fly ash effect on improving soil properties and rice productivity in Korean paddy soils. Bioresource Technol. 97, 1490, 2006.

24. INTHASAN J., HIRUNBURANA N., HERRMANN L., STAHR K. Effects of fly ash application on soil properties, nutrient status and environment in Northern Thailand. $17^{\text {th }}$ WCSS, 14-21 August 2002, Thailand, Symhosium No. 24, Paper No. 249, 1, 2002.

25. IUSS Working Group WRB. World Reference Base for Soil Resources 2014. International soil classification system for naming soils and creating legends for soil maps. World Soil Resources Reports No. 106. FAO, Rome, 2014. www.fao.org/3/a-i3794e.pdf

26. OSTROWSKAA., GAWLIŃSKI S., SZCZUBIAŁKAZ. Soil total nitrogen determination according to modified Kjeldahl's method. Methods of analysis and assessment of soil and plants properties, IOŚ Warszawa, 95, 1991 [In Polish].

27. LITYŃSKI T., JURKOWSKA H., GORLACH E. Determination of available phosphorus and potassium with Egner-Riehm method. Agro-chemical Analyses, Gleba i Nawozy. PWN Warszawa, 149, 1976 [in Polish].
28. LITYŃSKI T., JURKOWSKA H., GORLACH E. Determination of available magnesium with Schchtschabel's method. Agro-chemical Analyses, Gleba i Nawozy. PWN Warszawa, 157, 1976 [In Polish].

29. OSTROWSKA A., GAWLIŃSKI S., SZCZUBIAŁKA Z. Soil acidity determination - concentration of hydrogen ions $(\mathrm{pH})$. Methods of analysis and assessment of soil and plants properties, IOŚ Warszawa, 47, 1991 [In Polish].

30. SKALAR. Skalar Methods. Analysis: Nitrate+Nitrite. Catnr 461-852 issue 121093/MH/93128590, http://www.fh-bingen. de/uploads/media/SKALAR-Methode_Nitrat_02.pdf

31. SKALAR. Skalar Methods. Analysis: Ammonia. Catnr 155321 issue 112494/MH/94156160, www.fh-bingen. de/uploads/media/SKALAR-Methode_Ammonium_02.pdf

32. OSTROWSKA A., GAWLIŃSKI S., SZCZUBIAĒKA Z. Determination of oxidizable organic carbon according to modified Turin's method. Methods of analysis and assessment of soil and plants properties, IOŚ Warszawa, 89, 1991 [In Polish].

33. BURT R. Soil survey laboratory information manual. U.S. department of Agriculture, Natural Resources Conservation Service. Soil Survey investigations report No. 45, version 2.0. 2011.

http://www.nrcs.usda.gov/Internet/FSE_DOCUMENTS/ nrcs142p2_052226.pdf

34. STATSOFT. Statistica v. 10.0 (data analysis sotware system). 2010. www.statsoft.com

35. MICROSOFT. Excel 2010. 2010. www.microsoft.com

36. BURDZY J. Statistical Tables. Wydawnictwa Uczelniane Politechniki Lubelskiej, Lublin: pp. 60, 1999 [In Polish].

37. ANISWORTH C.C., RAI D. 1987. Chemical characterization of fossil fuel wastes. EPRIEA-5321. Electric Power Res. Inst., Palo, Alto 1987.

www.epri.com/abstracts/Pages/ProductAbstract.aspx? ProductId=EA-53211

38. RAUTARAYS K., GHOSH B.C., MITTRAB.N. Effect of fly ash, organic wastes and chemical fertilizers on yield, nutrient uptake, heavy metal content and residual fertility in a rice-mustard cropping sequence under acid lateritic soils. Bioresource Technol. 90, 275, 2003.

39. PATHAN, S.M., AYLMORE, L.A., COLMER, T.D. Soil properties and turf growth on a sandy soil amended with fly ash. Plant Soil 256, 103, 2003.

40. WŁAŚNIEWSKI S. Effect of hard coal fly ash fertilization on selected chemical properties of sandy soil and on oat yields. Ochr. Środ. Zas. Nat., 41, 479, 2009 [In Polish].

41. GIBCZYŃSKA M., STANKOWSKI S., HURY G., KUGLARZ K. Effects of limestone, ash from biomass and compost use on chemical properties of soil. Roczniki Gleboznawcze - Soil Science Annual 65, (2), 59, 2014.

42. GAIND S., GAUR A.C. Quality assessment of compost prepared from fly ash and crop residue. Bioresource Technol. 87, 125, 2003.

43. ADRIANO, D.C., WEBER, J.T. Influence of fly ash on soil physical properties and turf grass establishment. J. Environ. Qual. 30, 596, 2001

44. YELEDHALLI N.A., PRAKASH S.S., RAVI M.V. NARAYANA RAO K. Long-Term Effect of Fly Ash on Crop Yield and Soil Properties. Karnataka J. Agric. Sci., 21, (4), 507, 2008.

45. CIEĆKO Z., ŻOŁNOWSKI A.C., CHEŁSTOWSKI A. The residual effect of hard coal fly ash on the chemical composition of meadow sward. Zesz. Probl. Post. Nauk Rol. 518, 23, 2007 [In Polish]. 
46. GREWAL K.S., YADAV P.S., MEHTA S.C., OSWAL M.C. Direct and residual effect of fly ash application to soil on crop yield and soil properties. Crop Res. 21, 60, 2001.

47. RAMESH V., KORWAR G. R., MANDAL UTTAM KUMAR, PRASAD JASTI V. N. S., SHARMA KISHORILAL, YEZZU S. RAMAKRISHNA, KANDULA VENKANNA. Influence of fly ash mixtures on early tree growth and physicochemical properties of soil in semi-arid tropical Alfisols. Agroforest Syst. 73, 13, 2008.

48. SIEBIELEC G., SMRECZAK B., KLIMKOWICZPAWLAS A., MALISZEWSKA-KORDYBACH B., TERELAK H., KOZA P., HRYŃCZUK B., ŁYSIAK M.,
MITURSKI T., GAŁAZKA R., SUSZEK B. Chemistry monitoring of arable soils in Poland in 2010-2012. IUNGPIB. Puławy: pp. 202, 2012 [In Polish].

49. PALUMBO A.V., MCCARTHY J.F., AMONETTEJ.E., FISHER L.S., WULLSCHLEGER S.D., DANIELS W.L. Prospects for enhancing carbon sequestration and reclamation of degraded lands with fossil-fuel combustion by-products. Adv Environ. Res., 8, (3-4), 425, 2004.

50. SIX J., BOSSUYT H., DEGRYZE S., DENEF K. A history of research on the link between (micro) aggregates, soil biota, and soil organic matter dynamics. Soil Till. Res. 79, 7, 2004. 
